\title{
Behind the rankings of Pacific nations in the 2011-12 World Press Freedom Index
}

\section{COMMENTARY}

Australia and New Zealand both declined in the 2011-2012 Reporters Sans Frontières /Reporters Without Borders World Press Freedom Index rankings but all other surveyed Pacific Island nations improved their standings. This article reports upon those outcomes and details the methodology used by the international press freedom agency in reaching its annual determinations. It explains that such rankings can never be statistically precise because too many variables are at play between countries and from one survey period to another. Nevertheless, they are indicative and importantly draw attention each year to the widely varying standards applied to media freedom throughout the Pacific region and the wider world.

Keywords: ethics, media freedom, methodology, press freedom, regulation, self-regulation

\section{MARK PEARSON \\ Bond University, Australia}

\begin{abstract}
USTRALIA and New Zealand were both downgraded while other Pacific Island nations improved their rankings in the Reporters Sans Frontières (RSF-Reporters Without Borders) World Press places from 18th to 30th among the 179 countries ranked. New Zealand also dropped five places and out of the top 10 to 13 th position. But Papua New Guinea, Timor-Leste, Fiji, Samoa and Tonga all improved their rankings since the last survey in 2010. Other Pacific Island nations remained unranked
\end{abstract}


by RSF because of a lack of reliable, confirmed data in the form of returned questionnaires (RSF, 2012b). Those results and the organisation's methodology deserve explanation and debate. As RSF's Australian correspondent for

the past six years I offer some insights on both counts, although I am not a spokesperson for the organisation.

\section{The rankings-winners and losers}

First to the 2011-2012 rankings: what factors contributed to the ranked nations' elevation or decline in their media freedom status since 2010? This article will take a brief look at the conditions informing the performances of the ranked nations, with extra focus on Australia and New Zealand because of their downgrading. Perrottet and Robie (2011) offered an extended appraisal of the situation covering these and many more unranked nations in their Pacific Media Freedom 2011 status report.

Australia-down from 18 to 30

Over the past five years, Australia's ranking has fluctuated between 16 and 30 of the 179 countries surveyed, typically ahead of the United States but well behind New Zealand in its level of media freedom. The fact that there were six simultaneous inquiries into media regulation at the time it was being compiled (Christensen, 2011) sent a message to the international community that, for a Western democratic nation, the Australian government and its agencies were entertaining tougher regulatory measures. They included the Convergence Review, its subsidiary Independent Media Inquiry, the National Classification Scheme Review, the Commonwealth Government's Privacy Issues Paper, a Senate inquiry into $\mathrm{ABC}$ programming decisions and the Australian Communications and Media Authority's review of privacy guidelines for broadcasters. Between them they raised the prospect of new controls on print, broadcast and online media; a new tort of privacy; tough new classification systems across media; and the conversion of some selfregulatory bodies to regulatory status. RSF was so concerned by suggestions at the hearings of the Independent Media Inquiry that journalists should be licensed or that the Australian Press Council should be given powers to fine media organisations for ethical breaches that they issued a release on the matter (RSF, 2011).

The trial of Victorian police officer Simon Artz for alleged leaks to The Australian newspaper about a counter-terrorism operation raised several 
media freedom issues, with Crikey senior journalist Andrew Crook allegedly breaching a suppression order by revealing the name of a former member of Victoria's Special Intelligence Group involved in the hearing; warnings over Crikey journalist Margaret Simons live tweeting from the hearing; and The Australian's Cameron Stewart being ordered to reveal his sources (Pearson, 2012). Senior Fairfax executives were also summonsed by the Police Integrity Commission to produce documents revealing sources in September in relation to articles by Herald journalists Linton Besser and Dylan Welch about the NSW Crime Commission.

Victorian police launched an investigation into an alleged hacking of an Australian Labor Party electoral database by four journalists at The Age, including editor-in-chief Paul Ramage. Government control over media access to detention centres prompted condemnation from the journalists' union, the Media Entertainment and Arts Alliance. The Department of Immigration introduced new guidelines to restrict reporting of, and access to, detention centres. As an international NGO, Reporters Without Borders considers transparency and the free flow of information about governments' handling of refugees.

The Federal Court's ruling that hate speech laws should trump free expression was of concern when a judge ruled Herald Sun columnist Andrew Bolt breached the Racial Discrimination Act in his criticisms of fair-skinned indigenous people (Eatock $v$ Bolt [2011] FCA 1103). In May 2011, the ABC used a programming exemption to FOI laws to deny The Weekend Australian and Herald Sun access to its audience data and employee salaries. Earlier, Fairfax's deputy technology editor Ben Grubb, 20, was arrested after reporting on a conference presenter's alleged hacking at the AUSCert IT security conference.

RSF has also expressed concern for some years at the Federal government's determination to introduce an internet filtering scheme. While it still appeared unlikely the Australian government would have the political numbers to introduce its proposed internet filtering scheme, it had persuaded the major telecommunications providers and ISPs to adopt a "voluntary scheme" although they did not need to log or report incidents (ACMA, 2011). The government used the review of classification schemes across media as the reason for the delay in its pursuit of a mandatory filter. However, this could be read as a convenient political excuse for its lack of parliamentary numbers to advance its filtering proposal. 
All of this has happened against the backdrop of Australia being a rarity among democratic nations in not having freedom of the press or free expression stated explicitly in its Constitution and lacking a Bill of Rights where such freedoms are usually specified.

New Zealand-down from 10 to 13

New Zealand has been the region's highest ranking performer in the RSF Index for the past nine years. Although press freedom is not a constitutional right, freedom of expression is enshrined at Article 14 of the New Zealand Bill of Rights Act 1990.

Several factors contributed to New Zealand's fall from the top ten countries in the RSF 2011-12 Index. The introduction of video camera surveillance legislation prompted criticism that it undermined civil liberties and caused concern when it was used as the pretext for a police raid on three newsrooms in November 2011 in the hunt for a taped conversation between the Prime Minister John Key and a friend.

Government cuts to public broadcasting prompted the announced closure of TVNZ7 (later reversed), Radio New Zealand's Waatea News (Māori content) and Concert FM. There were also free expression concerns over the New Zealand Herald being banned from its parliamentary press gallery office as a punishment for publishing a photo of a protester trying to jump from the public gallery into the debating chamber (NZ Herald, 2011).

As in Australia, an inquiry into media regulation also raised concern. The Law Commission's inquiry into regulation recommended a single independent news media regulator (Law Commission, 2011).

Papua New Guinea - up from 42 to 35

Papua New Guinea was in political crisis at the end of 2011 and the start of 2012 as former Prime Minister Michael Somare tried to resume office and wrest control from new Prime Minister Peter O'Neil. The nation's vibrant media attempted to report developments as citizens turned to social media for their breaking news. Government pressure on NBC to suspend a senior news executive in late 2010 was a disturbing development, as was the use of the newspaper The National and threats of defamation action by Malaysian logging giant Rimbuan Hijau (RH) to intimidate other media over logging and land ownership stories. Members of Parliament demanded that reporters reveal sources of their stories exposing corruption. A continuing threat to 
media freedom was the exodus of senior journalists to higher paying positions in government and public relations.

Samoa-up from 111 to 54

Samoa's ranking improved markedly in a relatively quiet year for the repression of journalists. The major government move was offshore, in the form of an unsuccessful complaint to New Zealand's Broadcasting Standards Authority against TV3's Campbell Live report about the alleged misuse of tsunami aid funds (A-G Samoa and TVWorks Ltd). In June 2011, Tuala Iosefo Ponifasio' sued Samoan TV3 network manager Atanoa Herbert Crichton and reporter Tutuila Farao for libel.

Tonga-up from 87 to 63

The Tongan government continued to consider a licensing system for print media and government minister Clive Edwards won a \$14,275 defamation case against Kele'a over its pre-election articles. Despite discussions between the Tongan Media Council and the government, the country has yet to introduce freedom of information legislation.

Timor-Leste-up from 93 to 86

Government interference with the media was indirect, with media owners toeing the government line because of state funding of their enterprises. Supporters of some political parties threatened journalists who had written critical accounts. Government officers often refused to provide information to the media on sensitive issues.

Fiji-up from 149-117

The 2010 Media Industry Development Decree continued to have a detrimental impact on media freedom in Fiji, with the regime able to imprison and fine journalists and the Media Industry Development Authority supplanting the Fiji Press Council. The government's lifting in January 2012 of the Public Emergency Regulations laws that had banned public gatherings and censored the media raised hopes but it was yet to be seen whether the move would have any real impact on free expression.

\section{RSF's rankings process}

RSF's panel weighed this data against that provided from other countries as they compiled the latest World Press Index. While they have received advice on their methodology from the Statistics Institute of the University of Paris, 
RSF do not claim the index is a precise scientific measure. It could never be, given the enormous number of variables at stake, and that it has to rely on an element of expert qualitative judgment when making the final determinations of a country's comparative ranking. If it was purely quantitative, for example, there would be an inbuilt bias against the world's most populous countries because the sheer numbers of journalists and media organisations involved would increase the statistical likelihood of media freedom breaches or incidents involving journalists.

The process centres upon a questionnaire sent to partner organisations (18 freedom of expression groups in all five continents), to its network of 150 correspondents around the world, and to journalists, researchers, jurists and human rights activists (RSF, 2012b). The questionnaire features 44 main criteria indicative of the state of press freedom. It asks questions about every kind of violation directly affecting journalists and 'netizens' (including murders, imprisonment, physical attacks and threats) and news media (censorship, confiscation of newspaper issues, searches and harassment). It also measures the level of self-censorship in each country and the ability of the media to investigate and criticise. Points are allocated to each response in the survey and a scale devised by the organisation is then used to give a country score to each questionnaire. The 179 countries ranked are those for which RSF received completed questionnaires from several sources. The questionnaire takes account of the legal framework for the media (including penalties for press offences, the existence of a state monopoly for certain kinds of media and how the media are regulated) and the level of independence of the public media. It also reflects violations of the free flow of information on the internet.

I compare the process with the traditional approach academics have taken to essay marking in universities. Scores might be assigned to selected attributes using a rubric, but the process is ultimately a subjective one. That said, most academics arrive at very similar grades when called upon to remark an essay. They draw upon years of experience and countless earlier attempts by other students as their yardstick for assessing this one.

Many countries' rankings change from year to year but there is little movement at the extremes. Europe typically dominates the top 10, with Scandinavian countries such as Norway and Finland among the top few, while the usual suspects feature at the other end of the scale: Iran, North Korea, Vietnam, China, Burma, Turkmenistan and Eritrea. 
Free expression is not absolute, although its opposite — censorship — can be. The major difference between countries is the level of what lawyers call 'prior restraint' - censorship before publication or broadcast. Nations at the top of the scale have high levels of transparency and welcome media scrutiny of government processes, with a minimum of licensing and suppression and no physical intimidation of journalists. At the other extreme journalists are murdered, jailed and tortured, publishers of all kinds require a licence, and Internet access is restricted.

Governments might take issue with the methodology and argue over their precise rankings, but the index draws on the energies and acumen of experts in RSF's Paris headquarters and throughout the world; and is thus taken seriously in international circles. It serves to raise awareness about media and Internet freedom, which cannot be a bad thing in an age of government spin.

\section{References}

ACMA (2011, October 11). Internet Service Provider (ISP) filtering. Sydney: Australian Communications and Media Authority. Available:

www.dbcde.gov.au/funding_and_programs/cybersafety_plan/internet_service_provider_isp_filtering

Attorney-General of Samoa and TVWorks Ltd. (2011) Broadcasting Standards Authority (NZ) Number 2010-188. May 5, 2011. Available: www.bsa.govt.nz/ decisions/show/4165

Christensen, N. (2011, October 31). Too many questions in six inquiries frustrate industry. The Australian (Media section). Available: www.theaustralian.com. $\mathrm{au} / \mathrm{media} /$ digital/too-many-questions-in-six-inquiries-frustrate-industry/storyfna03wxu-1226180905880

Eatock v Bolt (2011) FCA 1103. Available: www.austlii.edu.au/au/cases/cth/ FCA/2011/1103.html

Law Commission (2012). The news media meets 'new media' [electronic resource]: rights, responsibilities and regulation in the digital age. (Issues paper ; 27). Available: http://ip27.publications.lawcom.govt.nz/chapter $+6+-+$ regulation + of + the+ media $+\% 96+a+$ new + regulator/entertainment

New Zealand Herald (2011, October 7). Speaker bans Herald for 10 days over photo in Parliament. nzherald.co.nz Available: www.nzherald.co.nz/nz/news/article. cfm?c id=1\&objectid=10757133

Pearson, M. (2012). Explaining Australia's fall in the RSF World Press Freedom Index. On Line Opinion-Australia's e-journal of social and political debate. 10 February 2012. Available: www.onlineopinion.com.au/view.asp?article=13228.

Perrottet, A. and Robie, D. (2011). Pacific media freedom 2011: A status report. Pacific Journalism Review, 17(2), pp. 148-186. 
RSF (2011, November 16). Press Council: regulation should not mean compulsion or restriction. Paris: Reporters Without Borders. Available: http://en.rsf.org/australiapress-council-regulation-should-16-11-2011,41402.html

RSF (2012a). 2011-12 World Press Freedom Index. Paris: Reporters Without Borders. Available: http://en.rsf.org/IMG/CLASSEMENT_2012/C_GENERAL_ANG.pdf RSF (2012b). 2011-2012 Press Freedom Index. How the index is compiled. Paris:

Reporters Without Borders. Available: http://en.rsf.org/IMG/pdf/how_the_20112012_index_was_compiled.pdf

Dr Mark Pearson is professor of journalism at Bond University, Queensland, Australia and Australian correspondent for Reporters Without Borders. An earlier version of this article focusing on Australia's ranking was published in On Line Opinion (Pearson, 2012). The author thanks Bob Howarth, Professor David Robie and Sarah Ruggiero for their assistance. mpearson@staff.bond.edu.au

The Journalism, Media and Democracy Research Centre invites papers for a one-day conference entitled:

\title{
AUSTRALIAN AND NEW ZEALAND MEDIA HISTORIES COMMONALITY, AUTONOMY, CONVERGENCE
}

Keynote speaker: Professor Peter Putnis, University of Canberra

\section{AUT University, Auckland, NZ | September 13, 2012}

\begin{abstract}
s settler societies, Australia and New Zealand experienced similar early histories in the
communcations field. Today, after a period of separate development, during which Aboriginal and Maori activist media openly challenged colonialist versions of history, the commonalities and differences of our media inhabit a global environment. With these thoughts in mind researchers are invited to submit papers in response to the following themes:

- Media organisations and news journalism

- Maori and Aboriginal media

- Political economies of media

- Australian and NZ media in Asia-Pacific

- Journalism, war and conflict

- Media representations of national identities

- Telecommunications

- Media and popular culture
\end{abstract}

\section{Abstracts due: June $\mathbf{3 0}$}

Send abstracts to Associate Professor Wayne Hope (wayne.hope@aut.ac.nz or jmad@aut.ac.nz). For further information contact Greg Treadwell (gregory.treadwell@aut.ac.nz).

Registration: NZ\$150 (Earlybird before June 30 \$110; student concession $\$ 60$ ) 